Annals of Plant and Soil Research 22(4): 336-348 (2020)

https://doi.org/10.47815/apsr.2020.10002

\title{
Effect of combined use of tillage and nutrient management practices on soil quality indicators and indices under maize (Zea mays) based cropping system in rainfed inceptisols
}

\section{K.L. SHARMA ${ }^{\#}$, G. RAVINDRA CHARY ${ }^{1}$, K. SAMMI REDDY ${ }^{1}$, MUNNA LAL ${ }^{1}$, A.P. SINGH ${ }^{2}$, VIKAS ABROL $^{2}$, ANIL SHARMA ${ }^{2}$, HEMANT DADHICH ${ }^{2}$, K. SRINIVAS ${ }^{1}$, K.A. GOPINATH ${ }^{1}$ AND A.K. INDORIA $^{1}$}

\author{
${ }^{1}$ ICAR-Central Research Institute for Dryland Agriculture, Hyderabad-500 059, Telangana \\ ${ }^{2}$ AICRP for Dryland Agriculture Dryland Agri. Res. Sub Station Rakh Dhiansar, Bari Brahmana, Jammu -181 \\ 133, Jammu \& Kashmir
}

Received: August, 2020; Revised accepted: October, 2020

\begin{abstract}
An experiment was conducted in the rainfed Inceptisols of Rakhdhiansar in Kandi areas of Western Himalayas of South Kashmir and Kumaon, India for four years to assess the influence of combined use of tillage and nutrient management treatments on soil quality under maize based cropping system. The experiment was initiated in a split plot design with three main and three sub-treatments using maize (Kanchan510) as the test crop. The main experimental treatments were: $T_{1}$ : Conventional Tillage (CT) +Two Intercultures (Two IC), $T_{2}$ : Low Tillage ( $\left.L T\right)+$ Two Intercultures (Two IC) and $T_{3}$ : Low Tillage $(L T)+$ Weedicide + One Interculture (One IC). The three sub treatments were, $T_{1}: 100 \% \mathrm{~N}$ through organic sources (compost), $T_{2}: 50 \%$ $N$ through organic sources $+50 \% N$ through inorganic sources and $T_{3}: 100 \% N$ through inorganic sources. The results of the present study clearly revealed that the tillage treatments did not significantly influence most of the soil quality parameters except available $S$, microbial biomass carbon (MBC) and Mean weight Diameter of Soil Aggregates (MWD). When averaged over nutrient levels, among the tillage practices, conventional tillage + Two IC recorded the highest available $S$ of $20.87 \mathrm{~kg} \mathrm{ha}^{-1}$. However, sub-sub treatments viz nutrient management significantly influenced the organic carbon (OC), available $N, P S$ and boron, dehyrogenase assay $(D H A)$, labile carbon (LC), bulk density (BD) and MWD. When averaged over tillage levels, the application of nutrients through inorganic sources recorded significantly highest available $N\left(160.50 \mathrm{~kg} \mathrm{ha}^{-1}\right), P\left(30.67 \mathrm{~kg} \mathrm{ha}^{-1}\right)$ and $\mathrm{K}\left(207.87 \mathrm{~kg} \mathrm{ha}^{-1}\right.$ in soil. Finally, in terms of Relative Soil Quality Indices (RSQI), Low tillage + Two IC (0.87) and Low tillage + Weedicide + One IC (0.89) proved superior compared to Conventional Tillage + 2 IC (0.82). Similarly, when averaged over tillage levels, the order of performance of nutrient management treatments was: $100 \% \mathrm{~N}$ through organic sources $(0.93)>50 \% \mathrm{~N}$ through organic sources $+50 \% \mathrm{~N}$ through inorganic sources $(0.84)>100 \% N$ through inorganic sources $(0.82)$. Though the interactions between tillage levels and nutrient management were not significant, but the combination of Low tillage practices with $100 \%$ organic Source of nutrients was quite superior in maintaining relatively higher RSQI. Thus, the results of the present study and methodology used will be highly useful to different stake holders associated withland and soil quality management.
\end{abstract}

Key words: Inceptisols, conventional tillage, nutrient management, interculture, soil quality indices

\section{INTRODUCTION}

The term Inceptisol is derived from the Latin word "inceptum", which means beginning. These soils are weakly developed, and are common in cool or dry climates with resistant or new parent material. These soils typically have a recognizable $A$ horizon, but only a weak $B$ horizon. In India, the area under Inceptisols soils is 95.8 million hectares, constituting $29.13 \%$ of total geographical area, which are mostly spread throughout the Indo-Gangetic Plain and along the lower courses of the country's major rivers (especially the deltas along the east coast).
There is no doubt that Inceptisol soils are agriculturally very important but they also pose the serious problems of soil erosion, low fertility, nutrient imbalance, and low soil organic matter, which limit productivity on a long-run basis. In the marginal regions, (Kandi areas), the important rainfed crops grown in Inceptisols are maize, pearl millet, green gram, black gram, groundnut, wheat, barley, lentil, mustard, taramira, and chick pea. The crop productivity of these soils is very poor because of several soilrelated productivity constraints. Sharma et al. (2004) and Sharma and Chaudhary (2007) reported that some of the important factors that

\footnotetext{
\#Corresponding author.kl.sharma@icar.gov.in
} 
contribute to accelerated depletion of micronutrients and secondary nutrients in Inceptisol soils could be intensive cultivation using high analysis nitrogen, phosphorus and potassium fertilizers, limited use of organic manures, and low or very low recycling of crop residue. Such degrading effects are more pronounced especially in stressed agroecologies such as hot semi-arid rainfed conditions (Suri 2007), where the soils encounter many constraints broadly on account of physical, chemical, and biological soil health and ultimately result in poor functional capacity, poor soil quality (AICRPDA 2003), and low productivity.

It has been understood that in most of the longterm experiments, the main research focus until the end of the 20th century was to monitor the increases in yields and individual changes in predominant soil parameters. Many reports in the past revealed that in order to quantitatively assess the effects of the long-term management systems or practices on the capacity of the soils to function, the research focus predominantly was on yield and chemical properties (Malhi et al. 2000), soil fertility and yield (Mohammad and Mohammad 1999), yield (Subbarao et al. 2000), physical properties (Unger et al. 1998), carbon pools (Campbell et al. 1998), chemical soil quality (Eck and Stewart 1998). The quantitative soil quality assessment using key indicator and integrated soil quality index approach has been a paradigm shift (Dalal and Moloney 2000; Andrews and Carroll 2001). Soil quality has been defined as the "capacity of the soil to function within ecosystem boundaries to sustain biological productivity, maintain environmental quality, and promote plant and animal health" (Doran and Parkin 1994). In the past, soil quality was understood as the inherent capacity of the soil to supply essential plant nutrients. Later, it was viewed as an abstract characteristic of soils that could not be defined because of its dependence on external factors such as land use and soil management practices, ecosystem and environmental interaction, socioeconomic and political priorities, and so on (Doran, et al. 1996).Maize is considered a promising option for diversifying agriculture in upland areas of India including the rainfed Inceptisols of Rakhdhiansar in Kandi areas of Western Himalayas of South Kashmir and Kumaon. Wheat is another important cereal crop grown in about 28.46 million ha in India. In marginal Inceptisol soils, it is grown as a rainfed crop. The productivityrelated soil constraints coupled with moisture scarcity under rainfed conditions limit the yield of both of these crops in marginal Inceptisol soils. Thus, the present study was initiated with the specific objectives of (i) quantifying the long-term effects of tillage and nutrient management on soil quality parameters (ii) identifying key indicators of soil quality, and (iii) assessing soil quality indices as influenced by the tillage and nutrient management treatments in marginal Inceptisol soils under a rainfed maize (Zea mays L.) based system.

\section{MATERIALS AND METHODS}

\section{Site description}

Out of the network centres of All India Coordinated Research Project for Dryland Agriculture (AICRPDA), under the technical and administrative jurisdiction of ICAR-Central Research Institute for Dryland Agriculture (CRIDA), the experimental location viz., Rakhdhiansar, is situated at $32^{\circ} 17^{\prime} \mathrm{N}$ latitude and $75^{\circ} 36^{\prime} \mathrm{E}$ longitude in Kandi areas of Western Himalayas of South Kashmir and Kumaon, warm moist to dry sub-humid transitional eco-sub-region (AESR 14.2) and it is at higher elevation than the other centres. The mean annual rainfall is $1180 \mathrm{~mm}$, of which 60 percent is received during July-August. Winter rains account for $225 \mathrm{~mm}$. Length of growing period is $150-210$ days. The soils are medium to deep loamy to clayey brown forest, podzolic and are medium deep sandy loam to loamy. Soils have medium available water capacity with neutral soil reaction and desirable electrical conductivity. Natively, the soils are low in organic carbon, nitrogen and phosphorus and low to medium in potassium.

\section{Experimental details}

A long term experiment was initiated during the year 2001 in a split plot design with three tillage treatments (main plot treatments) andthree nutrient management treatments as sub treatments with three replications using maize (Kanchan-510) as the test crop. The three main treatments were comprised of: $\mathrm{T}_{1}$ : Conventional Tillage (CT) + Two interculture 
Two IC), $\mathrm{T}_{2}$ : Low Tillage (LT) + Two Interculture (Two IC)and $\mathrm{T}_{3}$ : Low Tillage (LT) + Weedicide + One interculture (One IC). The three sub treatments included $\mathrm{T}_{1}: 100 \% \mathrm{~N}$ through Organic Sources (Compost), $\mathrm{T}_{2}: 50 \% \mathrm{~N}$ through Organic Sources $+50 \% \mathrm{~N}$ through Inorganic Sources and $T_{3}: 100 \% \mathrm{~N}$ through Inorganic Sources. To assess the influence of tillage and nutrient management practices on soil quality, the studies were taken up in this experimental site after the harvest of fourth year of crop.

\section{Soil sampling and analysis}

After 4 years of the experiment, surface soil samples were collected from plough layer (0.0-0.15 m depth). These samples were ground, partitioned and passed through standard prescribed sieves for further use in different kind of analysis. Soil samples passed through $8 \mathrm{~mm}$ sieve and retained on the $4.75 \mathrm{~mm}$ sieve were used for aggregate analysis, while the sample passed through $0.2 \mathrm{~mm}$ sieve was used for estimating organic carbon (OC) as well as labile carbon (LC). For the rest of the soil quality parameters viz., chemical and biological parameters, soil samples passed through $2 \mathrm{~mm}$ sieves were used. Soil $\mathrm{pH}$ was measured in 1:2 soil water suspensions, with $\mathrm{pH}$ meter. The electrical conductivity was measured in 1:2 soil water suspension using conductivity meter. Organic $C$ was determined by the modified Walkley - Black wet digestion method. Available nitrogen was estimated by alkaline- $\mathrm{KMnO}_{4}$ method. Bicarbonate-extractable $\mathrm{P}$ was extracted with $0.5 \mathrm{M}$ sodium bicarbonate $(\mathrm{pH}$ of 8.5) and was determined colorimetrically. Available Potassium (K) was extracted with neutral normal ammonium acetate solution and the extract was analyzed for potassium on inductively coupled plasma spectrophotometer (ICP-OES, GBC, Australian Model). Exchangeable $\mathrm{Ca}$ and $\mathrm{Mg}$ were also determined by using $1 \mathrm{~N}$ ammonium acetate solution as extractant and using atomic absorption spectrophotometer (GBC 906, Australian Model). Sulphur was extracted with $0.15 \% \mathrm{CaCl}_{2}$ reagent and was estimated turbidimetrically. The micronutrients viz., $\mathrm{Zn}, \mathrm{Fe}, \mathrm{Cu}$, and $\mathrm{Mn}$ were extracted using the method suggested by Lindsay and Norvell (1978) with Inductively Coupled Plasma Spectrophotometer (ICP), (model ICP-OES simultaneous system, GBC-
Australia) while, boron was estimated using DTPA-Sorbitol extraction method (Miller et al., 2001). Bulk density was measured by Keen box method. The distribution of water stable aggregates was determined by wet sieving technique using sieves of 4750 um, 2000 um, 1000um, 500um, 250um and 100um sizes (Yoder, 1936) and mean weight diameter (MWD) was computed after oven drying (van Bevel 1949). Dehydrogenase activity in the soils was measured by triphenyl tetrazolium chloride method (TTC) (Lenhard 1956). The results were expressed as mg TPF formed per hour per gm soil. Soil microbial biomass carbon (MBC) was determined using the chloroform fumigation incubation technique (Jenkinson and Powlson 1976). Immediately after collection, the portion of the $2 \mathrm{~mm}$ sieved samples was preserved in a horizontal refrigerator at $4-5^{\circ} \mathrm{C}$. Before analyzing MBC, these samples were taken out of the refrigerator and primed in $\mathrm{BOD}$ incubator at field capacity $(15 \% \mathrm{w} / \mathrm{w})$ moisture regime for 10 days at $25^{\circ} \mathrm{C} \pm 1^{\circ} \mathrm{C}$ temperature. Microbial biomass carbon was calculated using the following relationship

$\operatorname{MBC}\left(\mu g^{-1}\right.$ of soil $)=\left(E C_{F}-E C_{U F}\right) / K_{E C}$

Where, $E C_{F}$ is the total weight of extractable carbon in fumigated sample, $\mathrm{EC}_{\mathrm{UF}}$ is the total weight of the extractable carbon in unfumigated samples and $\mathrm{K}_{\mathrm{EC}}=0.25 \pm 0.05$ represents the efficiency of extraction of microbial biomass carbon. Labile carbon, which is also considered as one of the important biological soil quality indicators, was estimated using the method suggested by Weil et al., (2003) with slight modification. In this method, moist fresh air dried soil was equilibrated with 20 $\mathrm{ml} 0.01 \mathrm{M} \mathrm{KMnO}_{4}$ solution for 15 minutes. The soil-solution suspension was centrifuged at 3000 $\mathrm{rpm}$ for $5 \mathrm{~min}$. The absorbance was measured at $550 \mathrm{~nm}$ using Mini Spectrophotometer (Model SL 171 of Elico Ltd.).

\section{Soil quality indices- Steps for computation}

The rigorous data set obtained for all the 19 soil quality parameters was statistically analysed for their level of significance using split plot design. After the statistical analysis, the parameters which were found significant weresubjected to principal component analysis (PCA) 
using SPSS software (Version 12.0). The principal components (PC) which received eigen values $\geq 1$ (Brejda et al., 2000a, b) and explained at least $5 \%$ of the variation in the data (Wander and Bollero 1999) and variables which had high factor loading were considered as the best representative of system attributes. Within each PC, only highly weighted factors (having absolute values within $10 \%$ of the highest factor loading) were retained for the minimum data set (MDS). The variables qualified under these series of steps were termed as the 'key indicators' and were considered for computation of soil quality index (SQI) after suitable transformation and scoring.

All the observations of each identified key MDS indicators were transformed using linear scoring technique (Andrews et al., 2002a). To assign the scores, indicators were arranged in order depending on whether a higher value was considered "good" or "bad" in terms of soil function. In case of 'more is better' indicators, each observation was divided by the highest observed value such that the highest observed value received a score of 1 . For 'less is better' indicators, the lowest observed value (in the numerator) was divided by each observation (in the denominator) such that the lowest observed value received a score of 1 . After transformation using linear scoring, the MDS indicators for each observation were weighted using the PCA results. Each PC explained a certain amount (\%) of the variation in the total data set. This percentage when divided by the total percentage of variation explained by all PCs with eigenvectors $>1$, gave the weighted factors for indicators chosen under a given PC. After performing these steps, to obtain soil quality index (SQI), the weighted MDS indicator scores for each observation were summed up using the following function:

$$
\underset{\substack{\mathrm{S} I \\ \mathrm{~S}=1}}{\mathrm{~S}}(\mathrm{Wi} \times \mathrm{Si})
$$

Where, $\mathrm{Si}$ is the score for the subscripted variable and $\mathrm{Wi}$ is the weighing factor obtained from the PCA. Here the assumption is that, higher index scores meant better soil quality or greater performance of soil function. For better understanding and relative comparison of the long-term performance of the conjunctive nutrient use treatments, the SQI values were reduced to a scale of $0-1$ by dividing all the SQI values in the all the replications with the highest SQI value. The mean numerical value thus obtained, clearly reflects the relative performance of the management treatments, and hence was termed as the 'relative soil quality indices' (RSQI). Further, the percent contributions of each final key indicator towards SQI were also calculated and plotted in a pie chart.

\section{Statistical Analyses}

Analysis of variance (ANOVA) was performed using 'Drysoft' design package. split plot design was used for the experiment and the differences were compared by Least Significant Difference (LSD) test at a significance level of $p$ $<0.05$ (Snedecor et al., 1989). Principal component analysis was performed using SPSS 12 version.

\section{RESULTS AND DISCUSSIONS}

\section{Physico-chemical and chemical soil quality parameters}

Data revealed that, the soil reaction of the experimental plots was slightly acidic ranging from 6.02 to 6.54 and was not significantly influenced by any of the tillage and I nutrient management treatments (Table 1). Similarly, the soil $\mathrm{pH}$ and $\mathrm{EC}$ was also not influenced by any of the management practices and ranged between 0.05 and $0.08 \mathrm{dSm}^{-1}$. Organic carbon was observed to be low in these soils and varied from 4.17 to $5.25 \mathrm{~g} \mathrm{~kg}^{-1}$ across the treatments. Tillage did not show any significant influence on soil organic carbon but the nutrient management treatments showed a significant influence and when averaged over tillage levels, the application of nitrogen through $100 \%$ organic sources recorded the highest organic carbon content of $4.92 \mathrm{~g} \mathrm{~kg}^{-1}$ followed by the application of $100 \%$ inorganic sources $\left(4.58 \mathrm{~g} \mathrm{~kg}^{-1}\right)$. Among the macronutrients, tillage did not influence the available $\mathrm{N}, \mathrm{P}, \mathrm{K}$ status of soil significantly. However, the nutrient management treatments showed a significant influence on available $\mathrm{N}$ and $\mathrm{P}$ Available $\mathrm{N}$ was found to be very low in these soils and varied from 140.5 to $161.3 \mathrm{~kg}$ ha ${ }^{1}$ across the treatments while available $P$ varied 
from 20.5 to $32.1 \mathrm{~kg} \mathrm{ha}^{-1}$ and was found to be high. Among the nutrient management practices, on an average, application of nutrients through inorganic sources recorded significantly highest available $\mathrm{N}\left(159.7 \mathrm{~kg} \mathrm{ha}^{-1}\right)$ and $\mathrm{P}\left(30.9 \mathrm{~kg} \mathrm{ha}^{-1}\right)$.
In case of available $\mathrm{K}$, neither tillage nor the nutrient management treatments made any significant influence and it varied from 186.9 to $212.4 \mathrm{~kg} \mathrm{ha}{ }^{-1}$ across the management treatments (Fig 1).

Table 1: Effect of different tillage and nutrient management treatments on physico-chemical and chemical soil quality parameters (Primary Nutrients) under maize based cropping system in Inceptisols of Rakhdhiansar

\begin{tabular}{c|c|c|c|c|c|c|c|}
\hline Tillage & N Treatments & $\mathrm{pH}$ & $\begin{array}{c}\mathrm{EC} \\
\left(\mathrm{dS} \mathrm{m}^{-1)}\right.\end{array}$ & $\begin{array}{c}\mathrm{OC} \\
\left(\mathrm{g} \mathrm{kg}^{-1}\right)\end{array}$ & $\begin{array}{c}\mathrm{N} \\
\left(\mathrm{kg} \mathrm{ha}^{-1}\right)\end{array}$ & $\begin{array}{c}\mathrm{P} \\
\left(\mathrm{kg} \mathrm{ha}^{-1}\right)\end{array}$ & $\begin{array}{c}\mathrm{K} \\
\left(\mathrm{kg} \mathrm{ha}^{-1}\right)\end{array}$ \\
\hline Conventional & $\mathrm{T}_{1}$ & 6.12 & 0.06 & 4.63 & 149.1 & 25.1 & 188.3 \\
tillage+ Two IC & $\mathrm{T}_{2}$ & 6.02 & 0.05 & 4.17 & 145.9 & 22.8 & 186.9 \\
& $\mathrm{~T}_{3}$ & 5.93 & 0.06 & 4.67 & 160.1 & 31.2 & 212.4 \\
Low tillage + & $\mathrm{T}_{1}$ & 6.14 & 0.05 & 4.87 & 155.7 & 24.8 & 187.7 \\
Two IC & $\mathrm{T}_{2}$ & 6.04 & 0.07 & 4.30 & 150.1 & 22.1 & 192.2 \\
Low & $\mathrm{T}_{3}$ & 6.23 & 0.06 & 4.53 & 157.6 & 32.1 & 205.6 \\
tillage+weedicid & $\mathrm{T}_{1}$ & 6.54 & 0.07 & 5.25 & 140.5 & 20.5 & 197.3 \\
e+one IC & $\mathrm{T}_{2}$ & 6.48 & 0.07 & 4.52 & 146.3 & 25.3 & 205.3 \\
& $\mathrm{~T}_{3}$ & 6.47 & 0.08 & 4.55 & 161.3 & 29.6 & 198.8 \\
& Between two main treatment means & $\mathrm{NS}$ & $\mathrm{NS}$ & $\mathrm{NS}$ & $\mathrm{NS}$ & $\mathrm{NS}$ & $\mathrm{NS}$ \\
$\mathrm{CD} @(\mathrm{P}=0.05)$ & Between two sub treatment means & $\mathrm{NS}$ & $\mathrm{NS}$ & 0.38 & 10.6 & 4.65 & $\mathrm{NS}$ \\
& Between two sub treatment means at & $\mathrm{NS}$ & $\mathrm{NS}$ & $\mathrm{NS}$ & $\mathrm{NS}$ & $\mathrm{NS}$ & $\mathrm{NS}$ \\
& Same main treatments & & & & & & \\
& Between two main treatment means & $\mathrm{NS}$ & $\mathrm{NS}$ & $\mathrm{NS}$ & $\mathrm{NS}$ & $\mathrm{NS}$ & $\mathrm{NS}$ \\
\hline & at same or different sub treatments & $\mathrm{NS}$ & & & & &
\end{tabular}

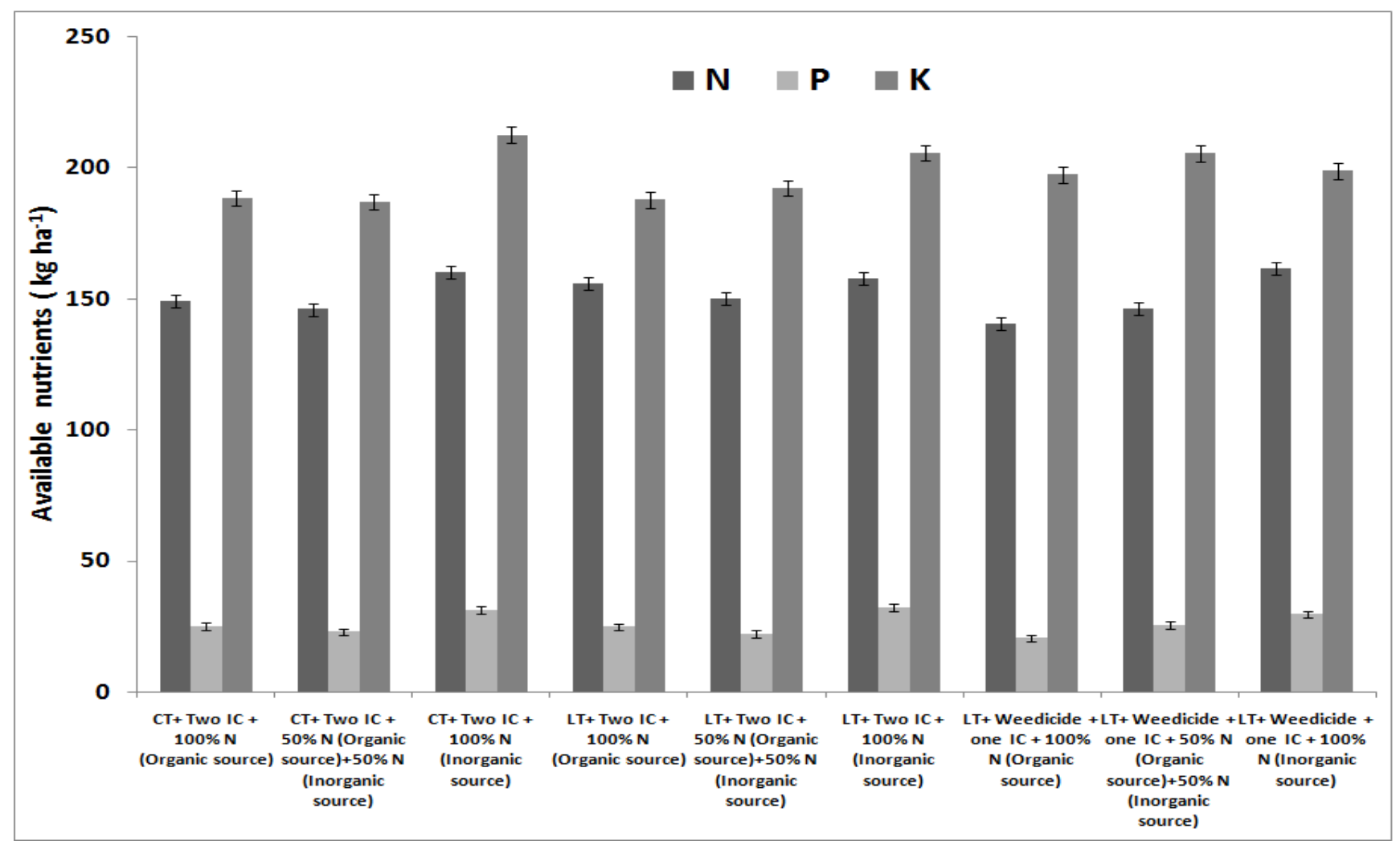

Fig 1: Effect of different tillage and nutrient management treatments on chemical soil quality parameters under maize based cropping system in Inceptisols of Rakhdhiansar 
Chemical soil quality parameters (secondary and micronutrients)

Among the secondary nutrients, the tillage and nutrient management treatments did not show any significant influence on exchangeable $\mathrm{Ca}$ and $\mathrm{Mg}$ and varied from 2.00 to 3.18 and 0.55 to $0.73 \mathrm{c} \mathrm{mol} \mathrm{kg}{ }^{-1}$ respectively across the management treatments (Table 2 \& Fig 2). But available $S$, varying from 16.2 to 23.4 $\mathrm{kg} \mathrm{ha}^{-1}$ was significantly influenced by both tillage and nutrient management treatments. Among the tillage practices, on an average, practice of conventional tillage + one interculture operation recorded the highest available $S$ of $20.8 \mathrm{~kg} \mathrm{ha}^{-1}$ while among the nutrient treatments, the application of nutrient through organic sources showed the highest available $S$ $\left(21.9 \mathrm{~kg} \mathrm{ha}^{-1}\right)$. Among the micronutrients, available $\mathrm{Fe}$ and $\mathrm{Mn}$ were not influenced by any of the management treatments and varied from 10.6 to $13.8 \mu \mathrm{g} \mathrm{g}^{-1}$ and 11.7 to $14.9 \mu \mathrm{g} \mathrm{g}^{-1}$ across the management treatments. Similarly, the available $\mathrm{Zn}$ and $\mathrm{Cu}$ whichvaried from 1.18 to $1.87 \mu \mathrm{g} \mathrm{g}^{-1}$ and 0.45 to $0.59 \mu \mathrm{g} \mathrm{g}^{-1}$ across the management treatments were also not significantly influenced by tillage and nutrient management treatments but their interaction effects were significant. Tillage did not significantly influence the available B content but the nutrient management treatments showed a significant influence, where application of $100 \%$ organic sources recorded the highest available $B$ content $\left(0.65 \mu \mathrm{g} \mathrm{g}^{-1}\right)$ (Fig 3).

Table 2: Effect of different tillage and nutrient management treatments on chemical soil quality parameters (secondary and micronutrients) under maize cropping system in Inceptisols

\begin{tabular}{|c|c|c|c|c|c|c|c|c|c|}
\hline Tillage & N Treatments & $\begin{array}{c}\mathrm{Ca} \\
\left(\mathrm{cmol} \mathrm{kg}^{-1}\right)\end{array}$ & $\begin{array}{c}\mathrm{Mg} \\
\left(\mathrm{cmol} \mathrm{kg}^{-1}\right)\end{array}$ & $\begin{array}{c}\mathrm{S} \\
\left(\mathrm{kg} \mathrm{ha}^{-1}\right)\end{array}$ & $\begin{array}{c}\mathrm{Zn} \\
\left(\mu g g^{-1}\right)\end{array}$ & \begin{tabular}{|c|}
$\mathrm{Fe}$ \\
$\left(\mu \mathrm{g} \mathrm{g}^{-1}\right)$
\end{tabular} & $\begin{array}{c}\mathrm{Cu} \\
\left(\mu \mathrm{g} \mathrm{g}^{-1}\right)\end{array}$ & \begin{tabular}{|c|}
$\mathrm{Mn}$ \\
$\left(\mu \mathrm{g} \mathrm{g}^{-1}\right)$
\end{tabular} & $\begin{array}{c}B \\
\left(\mu g^{-1}\right)\end{array}$ \\
\hline Conventional & $\mathrm{T}_{1}$ & 2.76 & 0.72 & 23.4 & 1.32 & 10.6 & 0.50 & 14.1 & 0.63 \\
\hline tillage+ Two & $\mathrm{T}_{2}$ & 2.57 & 0.68 & 20.3 & 1.25 & 12.8 & 0.55 & 14.5 & 0.54 \\
\hline IC & $\mathrm{T}_{3}$ & 2.00 & 0.56 & 18.9 & 1.61 & 13.8 & 0.55 & 14.0 & 0.47 \\
\hline \multirow{3}{*}{$\begin{array}{l}\text { Low tillage }+ \\
\text { Two IC }\end{array}$} & $\mathrm{T}_{1}$ & 2.41 & 0.59 & 20.5 & 1.62 & 11.5 & 0.45 & 11.7 & 0.64 \\
\hline & $\mathrm{T}_{2}$ & 2.57 & 0.56 & 16.6 & 1.87 & 12.9 & 0.53 & 14.4 & 0.58 \\
\hline & $\mathrm{T}_{3}$ & 2.85 & 0.64 & 17.7 & 1.20 & 11.9 & 0.59 & 14.9 & 0.48 \\
\hline \multirow{5}{*}{$\begin{array}{l}\text { Low tillage + } \\
\text { weedicide + } \\
\text { one IC }\end{array}$} & $\mathrm{T}_{1}$ & 2.82 & 0.73 & 21.9 & 1.19 & 12.0 & 0.59 & 13.8 & 0.68 \\
\hline & $\mathrm{T}_{2}$ & 2.93 & 0.55 & 17.5 & 1.18 & 12.3 & 0.47 & 12.2 & 0.66 \\
\hline & $\mathrm{T}_{3}$ & 3.18 & 0.60 & 16.2 & 1.39 & 13.3 & 0.59 & 14.9 & 0.53 \\
\hline & $\begin{array}{c}\text { Between two } \\
\text { maintreatment means }\end{array}$ & NS & NS & 2.00 & NS & NS & NS & NS & NS \\
\hline & $\begin{array}{c}\text { Between two } \\
\text { subtreatment means }\end{array}$ & NS & NS & 1.72 & NS & NS & NS & NS & 0.07 \\
\hline \multirow[t]{2}{*}{$\begin{array}{c}C D @ \\
(P=0.05)\end{array}$} & $\begin{array}{c}\text { Between two sub } \\
\text { treatment means at } \\
\text { same maintreatments }\end{array}$ & NS & NS & NS & 0.37 & NS & 0.10 & NS & NS \\
\hline & $\begin{array}{l}\text { Between two } \\
\text { maintreatment means } \\
\text { atsame or different } \\
\text { sub treatments }\end{array}$ & NS & NS & NS & 0.41 & NS & 0.09 & NS & NS \\
\hline
\end{tabular}




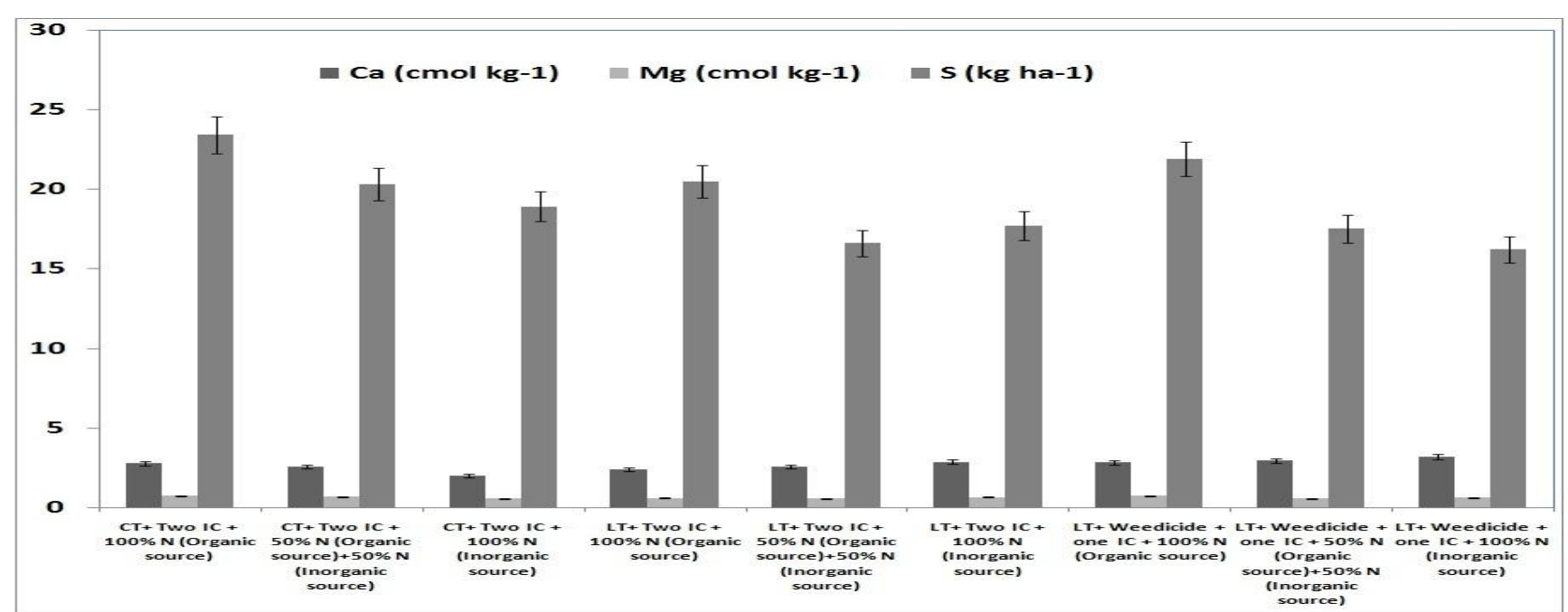

Fig 2: Effect of different tillage and nutrient management treatments on chemical soil quality parameters (secondary nutrients) under maize based cropping system in Inceptisols of Rakhdhiansar

\section{Biological and physical soil quality parameters}

Among the biological soil quality parameters, the significant influence of tillage was observed only on microbial biomass carbon, while the nutrient management treatments showed a significant influence on both dehydrogenase activity and labile carbon (Table 3 \& Fig 4). The interaction effects of tillage as well as the nutrient management treatments did not have any significant influence on any of the biological soil quality parameters. However, dehydrogenase activity varied from 1.47 to 2.43 $\mu \mathrm{g}$ TPF $\mathrm{hr}^{-1} \mathrm{~g}^{-1}$, microbial biomass carbon varied from 161.2 to $193.1 \mu \mathrm{g} \mathrm{g}^{-1}$ of soil and labile carbon varied from 268.1 to $324.5 \mu \mathrm{g} \mathrm{g}^{-1}$ of soil across the management treatments. On an average, among the tillage practices, the practice of conventional tillage + Two interculture operation showed highest microbial biomass practice of conventional tillage + Two interculture operation showed highest microbial biomass carbon of $187.1 .0 \mu \mathrm{g} \mathrm{g}^{-1}$ of soil while among the nutrient management practices, the application of nutrients through $100 \%$ organic sources significantly influenced the dehydrogenase

Table 3: Effect of different tillage and nutrient management treatments on biological and physical soil quality parameters under maize cropping system

\begin{tabular}{|c|c|c|c|c|c|c|}
\hline Tillage & $\mathrm{N}$ Treatments & $\begin{array}{c}\text { DHA } \\
\left(\mu \mathrm{g} \mathrm{TPF} \mathrm{hr}^{-1} \mathrm{~g}^{-1}\right)\end{array}$ & $\begin{array}{c}\mathrm{MBC} \\
\left(\mu \mathrm{gg}^{-1} \text { of soil }\right)\end{array}$ & $\begin{array}{c}\mathrm{LC} \\
\left(\mu \mathrm{g} \mathrm{g}^{-1} \text { of soil) }\right.\end{array}$ & $\begin{array}{c}\mathrm{BD} \\
\left(\mathrm{Mg} \mathrm{m}^{-3}\right)\end{array}$ & $\begin{array}{l}\text { MWD } \\
(\mathrm{mm})\end{array}$ \\
\hline Convention & $T_{1}$ & 2.10 & 188.4 & 294.5 & 1.50 & 0.17 \\
\hline al tillage+ & $\mathrm{T}_{2}$ & 1.66 & 185.7 & 275.2 & 1.34 & 0.16 \\
\hline Two IC & $\mathrm{T}_{3}$ & 1.71 & 187.3 & 278.3 & 1.58 & 0.16 \\
\hline Low tillage & $T_{1}$ & 2.16 & 193.1 & 316.2 & 1.50 & 0.25 \\
\hline \multirow[t]{2}{*}{ + Two IC } & $\mathrm{T}_{2}$ & 1.91 & 185.3 & 268.1 & 1.56 & 0.18 \\
\hline & $\mathrm{T}_{3}$ & 1.47 & 179.2 & 278.7 & 1.61 & 0.19 \\
\hline Low tillage & $\mathrm{T}_{1}$ & 2.43 & 161.2 & 324.5 & 1.50 & 0.25 \\
\hline + weedicide & $\mathrm{T}_{2}$ & 1.97 & 162.1 & 296.7 & 1.50 & 0.20 \\
\hline \multirow{5}{*}{$\begin{array}{l}\text { + one IC } \\
\text { CD @ } \\
(P=0.05)\end{array}$} & $\mathrm{T}_{3}$ & 1.86 & 173.3 & 285.5 & 1.54 & 0.18 \\
\hline & $\begin{array}{l}\text { Between two main treatment } \\
\text { means }\end{array}$ & & & & & \\
\hline & $\begin{array}{c}\text { Between two sub treatment } \\
\text { means }\end{array}$ & NS & 12.8 & NS & NS & 0.02 \\
\hline & $\begin{array}{l}\text { Between two sub treatment } \\
\text { means at same main treatments }\end{array}$ & 0.26 & NS & 19.8 & 0.06 & 0.02 \\
\hline & $\begin{array}{l}\text { Between two main treatment } \\
\text { means at same or different sub } \\
\text { treatments }\end{array}$ & NS & NS & NS & 0.10 & 0.03 \\
\hline
\end{tabular}




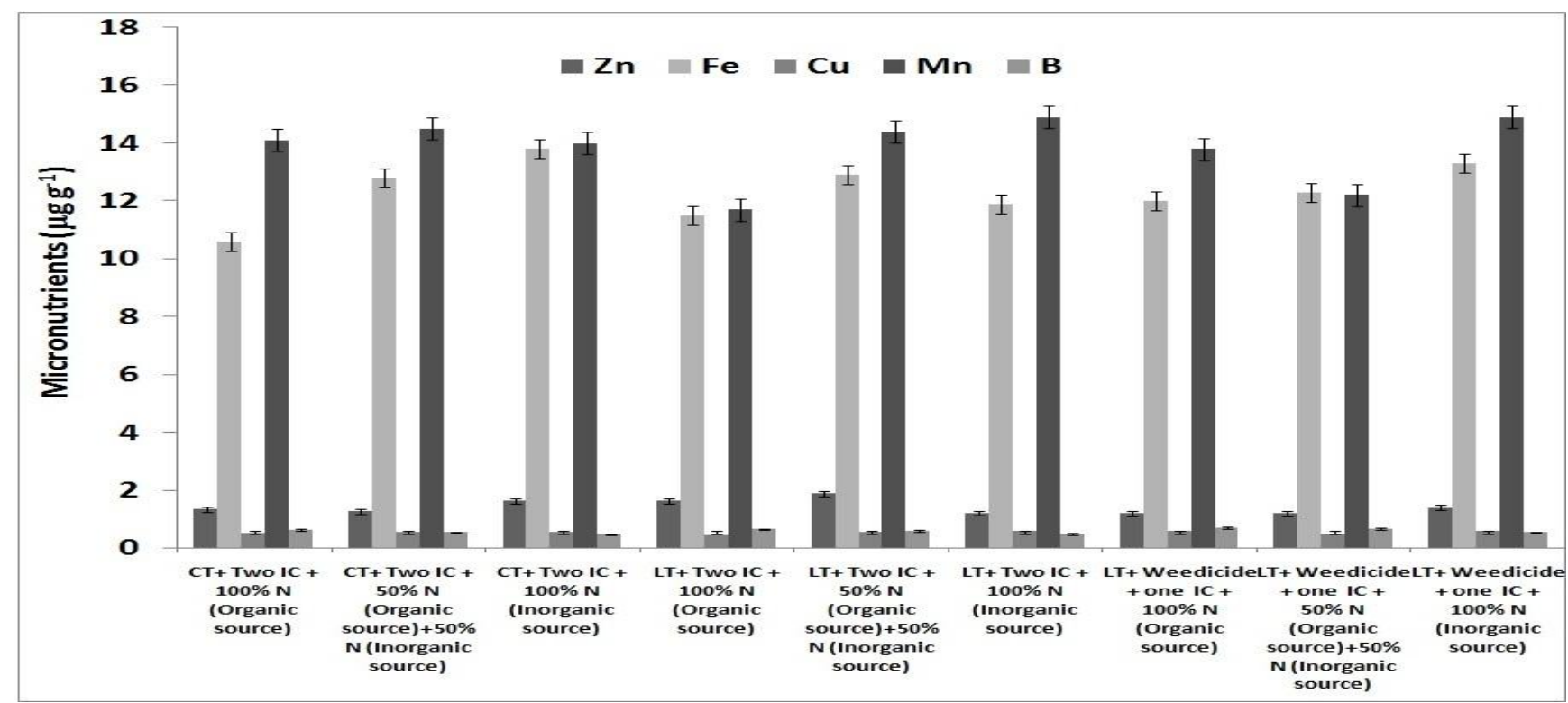

Fig 3: Effect of different tillage and nutrient management treatments on chemical soil quality parameters (micronutrients) under maize cropping system in Inceptisols of Rakhdhiansar

activity $\left(2.23 \mu \mathrm{g}\right.$ TPF $\left.\mathrm{hr}^{-1} \mathrm{~g}^{-1}\right)$ and labile carbon (311.7 $\mu \mathrm{g} \mathrm{g}^{-1}$ of soil). Bulk density of these soils varied from 1.34 to $1.61 \mathrm{Mg} \mathrm{m}^{-3}$ while the mean weight diameter of the soil aggregates varied from 0.16 to $0.25 \mathrm{~mm}$ across the management treatments. When averaged over nutrient levels, the practice of Low tillage + weedicide + one IC and Low tillage +IC maintained significantly highest mean weight diameter $(0.21 \mathrm{~mm})$ and were at par with each other. While the bulk density was not influenced by any of the tillage practices. Among the nutrient management practices, the application of nutrients through $100 \%$ organic sources recorded significantly highest mean weight diameter of $0.22 \mathrm{~mm}$ while the conjunctive application of nutrients significantly influenced the bulk density $(1.47 \mathrm{Mg}$ $\mathrm{m}^{-3}$ ) (Fig 5). Earlier researchers (Sharma et al 2019a and Sharma et al 2019b) also reported significant effect of soil management practices on soil physical, chemical and biological properties in Inceptisol and Vertisol soils.

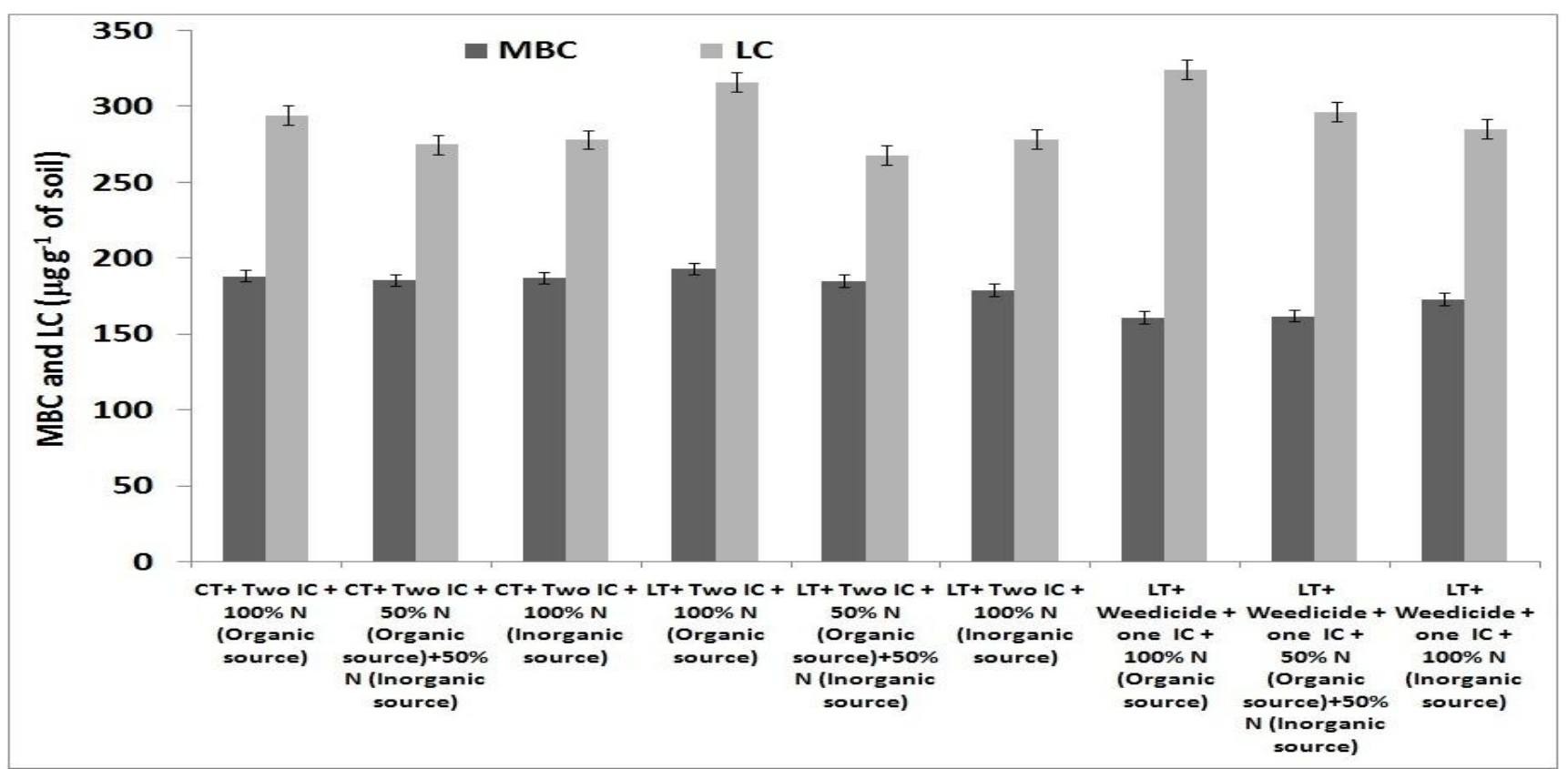

Fig 4: Effect of different tillage and nutrient management treatments on biological soil quality parameters under maize cropping system 


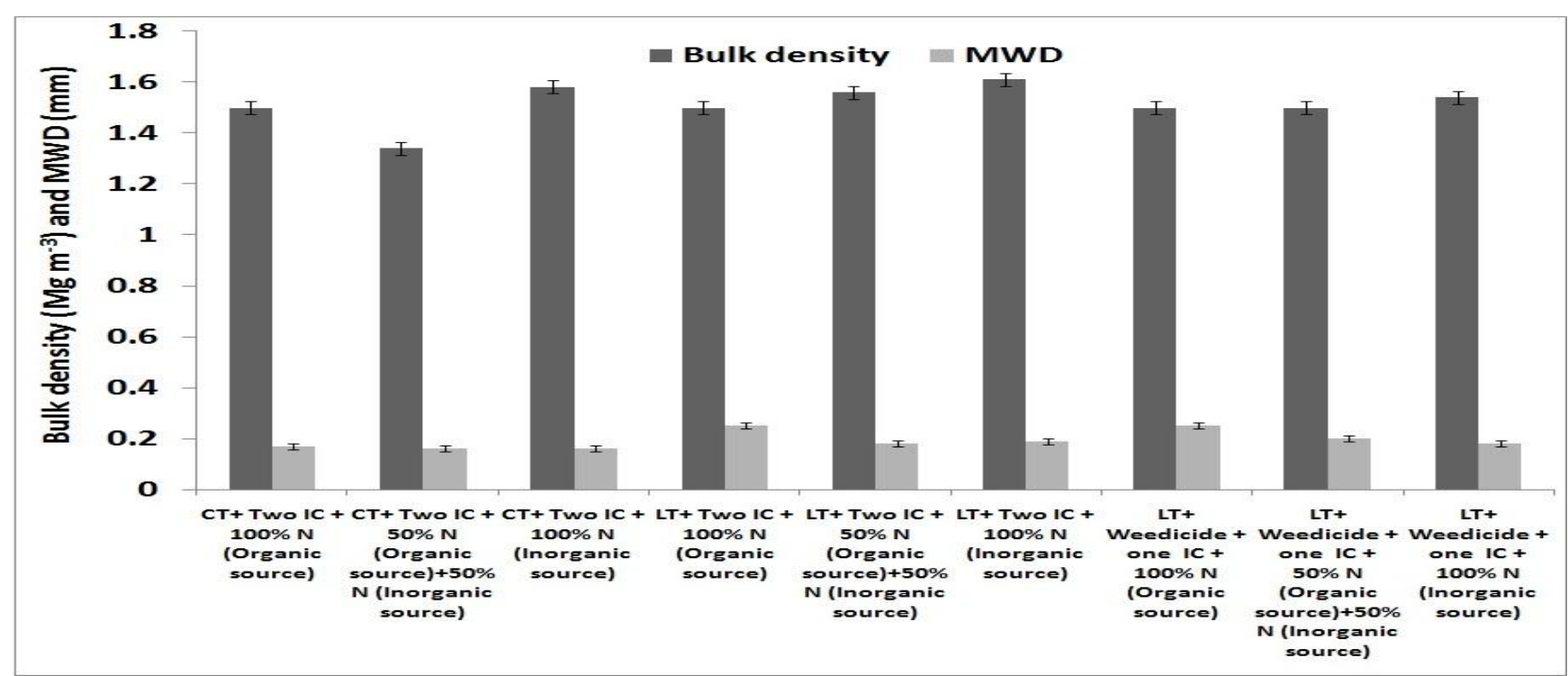

Fig 5: Effect of different tillage and nutrient management treatments on physical soil quality parameters under maize based cropping system

\section{Key indicators and soil quality assessment}

The influence of tillage and nutrient management treatments practiced under maize cropping system on 19 soil quality parameters were studied. The statistical analysis of these parameters revealed that out of these 19 soil quality parameters, 7 parameters viz., $\mathrm{pH}$, EC, available $\mathrm{K}$, exchangeable $\mathrm{Ca} \& \mathrm{Mg}$, and available Fe \& Mn were not found significant and hence were not included for further PCA analysis. The other 12 parameters, which showed significance either with the main treatment or their interaction effects, were considered for the PCA.The PC analysis carried out with 12 significant variables gave four PCs which had eigen values $>1$ and explaining about
$67.9 \%$ variance in the data set (Table 4). Out of the four PCs, in the PC1 three variables viz., available $B$, labile carbon and mean weight diameter emerged as the highly weighted variables while in $\mathrm{PC} 2, \mathrm{PC} 3$ and $\mathrm{PC} 4$, only single variables viz., available $P$, available $Z n$ and available $S$, respectively, were found to be highly weighted. The correlation matrix run for the variables under $\mathrm{PC} 1$ revealed insignificant relation between the parameters and hence all the parameters under PC1 were considered for the final MDS (Table 5). Hence, the six indicators retained for the final MDS included available $\mathrm{P}$, available $\mathrm{S}$, available $\mathrm{Zn}$ and $\mathrm{B}$, labile carbon and mean weight diameter and were termed as the key indicators for maize cropping system in Inceptisols of Rakhdhiansar.

Table 4: Principal component analysis of soil quality parameters as influenced by tillage and nutrient management treatments under maize based cropping system

\begin{tabular}{l|c|c|c|}
\hline \multicolumn{1}{c|}{ Tillage } & $\mathrm{N}$ Treatments & $\mathrm{SQI}$ & $\mathrm{RSQI}$ \\
\hline Conventional & $\mathrm{T}_{1}$ & 1.41 & 0.87 \\
tillage+ Two IC & $\mathrm{T}_{2}$ & 1.28 & 0.79 \\
& $\mathrm{~T}_{3}$ & 1.31 & 0.81 \\
Low tillage + & $\mathrm{T}_{1}$ & 1.58 & 0.97 \\
Two IC & $\mathrm{T}_{2}$ & 1.36 & 0.84 \\
& $\mathrm{~T}_{3}$ & 1.33 & 0.82 \\
Low tillage + & $\mathrm{T}_{1}$ & 1.56 & 0.96 \\
weedicide + one & $\mathrm{T}_{2}$ & 1.44 & 0.89 \\
$\mathrm{IC}$ & $\mathrm{T}_{3}$ & 1.35 & 0.83 \\
$\mathrm{CD} @(\mathrm{P}=0.05)$ & Between two main treatment means & $\mathrm{NS}$ & $\mathrm{NS}$ \\
& Between two sub treatment means & $* *$ & $*$ \\
& Between two sub treatment means at same main treatments & $\mathrm{NS}$ \\
\cline { 2 - 4 } & Between two main treatment means at same or different sub treatments & $\mathrm{NS}$ & $\mathrm{NS}$ \\
\hline
\end{tabular}


Table 5: Pearson's Correlation matrix for highly weighted variables under PC's with high factor loading

\begin{tabular}{ll|l|l|}
\hline Variables under PCs & & & \\
\hline PC1 & B & LC & MWD \\
B & 1.00 & $0.649^{* *}$ & $0.496^{* *}$ \\
LC & $0.649^{* *}$ & 1.00 & $0.649^{* *}$ \\
MWD & $0.496^{* *}$ & $0.649^{* *}$ & 1.00 \\
Correlation sum & 2.145 & 2.298 & 2.145 \\
\hline
\end{tabular}

"Correlation is significant at $P=0.05$ level

${ }^{*}$ correlation is significant at $P=0.01$ level

\section{Soil quality indices}

Soil quality indices were computed using the six key indicators retained in the final MDS viz., available $P$, available $S$, available $Z n \& B$, labile carbon and mean weight diameter. The statistical analysis revealed that the tillage treatments did not show any significant influence in improving the soil quality while the nutrient management treatments played a significant role in maintaining the soil quality. The soil quality indices varied between 1.28 to 1.58 and the relative soil quality indices varied between 0.79 to 0.97 , across the management treatments (Table 6\& Fig 6). Among the nutrient management treatments, the application of
$100 \% \mathrm{~N}$ through organic sources maintained significantly highest soil quality (1.51) followed by application of $50 \% \mathrm{~N}$ through organic sources $+50 \% \mathrm{~N}$ through inorganic sources (1.36) which was at par with the application of $100 \% \mathrm{~N}$ through inorganic sources (1.33). The percent contribution of these key indicators towards soil quality indices was as follows: available $P$ (11.0\%), available S (7.23\%), available $\mathrm{Zn}$ $(8.99 \%)$, available B $(23.3 \%)$, labile carbon $(26.6 \%)$ and mean weight diameter $(22.9 \%)$ (Fig 7). The order of performance of the tillage and nutrient management treatments in terms of Relative Soil Quality Indices (RSQI) was as follows: $\mathrm{LT}+$ Two IC $+100 \% \mathrm{~N}$ (organic source/compost $(0.97)>\mathrm{LT}+$ Weedicide + One IC $+100 \% \mathrm{~N}$ (organic source/compost) $(0.96)>$ $\mathrm{LT}+$ Weedicide + One IC + 50\% N (organic) + $50 \%$ (inorganic source $(0.89)>\mathrm{CT}+$ Two IC + $100 \% \mathrm{~N}$ (organic source/compost) $(0.87)>\mathrm{LT}+$ Two IC $+50 \% \mathrm{~N}$ (organic) $+50 \%$ (inorganic source) $>(0.84)>\mathrm{LT}+$ Weedicide + One IC + $100 \% \mathrm{~N}$ (inorganic source) $(0.83)>\mathrm{LT}+\mathrm{IC}+$ $100 \% \mathrm{~N}$ (inorganic source) $(0.82)>C T+$ Two IC $+100 \% \mathrm{~N}$ (inorganic source) $(0.81)>\mathrm{CT}+$ Two IC $+50 \% \mathrm{~N}$ (organic) $+50 \%$ (inorganic source) ( 0.79 )

Table 6: Soil quality indices (SQI) and relative soil quality indices (RSQI) as influenced by different tillage and nutrient management treatments under maize based cropping system

\begin{tabular}{c|l|c|c|}
\hline S. No. & \multicolumn{1}{|c}{ Name of the treatments } & SQI & RSQI \\
\hline 1 & CT + Two IC + 100\% N (organic source/compost) & 1.41 & 0.87 \\
2 & CT + Two IC + 50\% N (organic) + 50 \% (inorganic source) & 1.28 & 0.79 \\
3 & CT + Two IC + 100\% N (inorganic source) & 1.31 & 0.81 \\
4 & LT + Two IC + 100\% N (organic source/compost) & 1.58 & 0.97 \\
5 & LT + Two IC + 50\% N (organic) + 50\% (inorganic source) & 1.36 & 0.84 \\
6 & LT + IC + 100\% N (inorganic source) & 1.33 & 0.82 \\
7 & LT + Weedicide + One IC + 100\% N (organic source/compost) & 1.56 & 0.96 \\
8 & LT + Weedicide + One IC + 50\% N (organic) + 50\% (inorganic source) & 1.44 & 0.89 \\
9 & LT + Weedicide + One IC + 100\% N (inorganic source) & 1.35 & 0.83 \\
& CD @ (P= 0.05) & & \\
& Between two main treatment means & NS & NS \\
& Between two sub treatment means & $* *$ \\
& Between two sub treatment means at same main treatments & NS & NS \\
& Between two main treatment means at same or different sub treatments & NS & NS \\
\hline
\end{tabular}




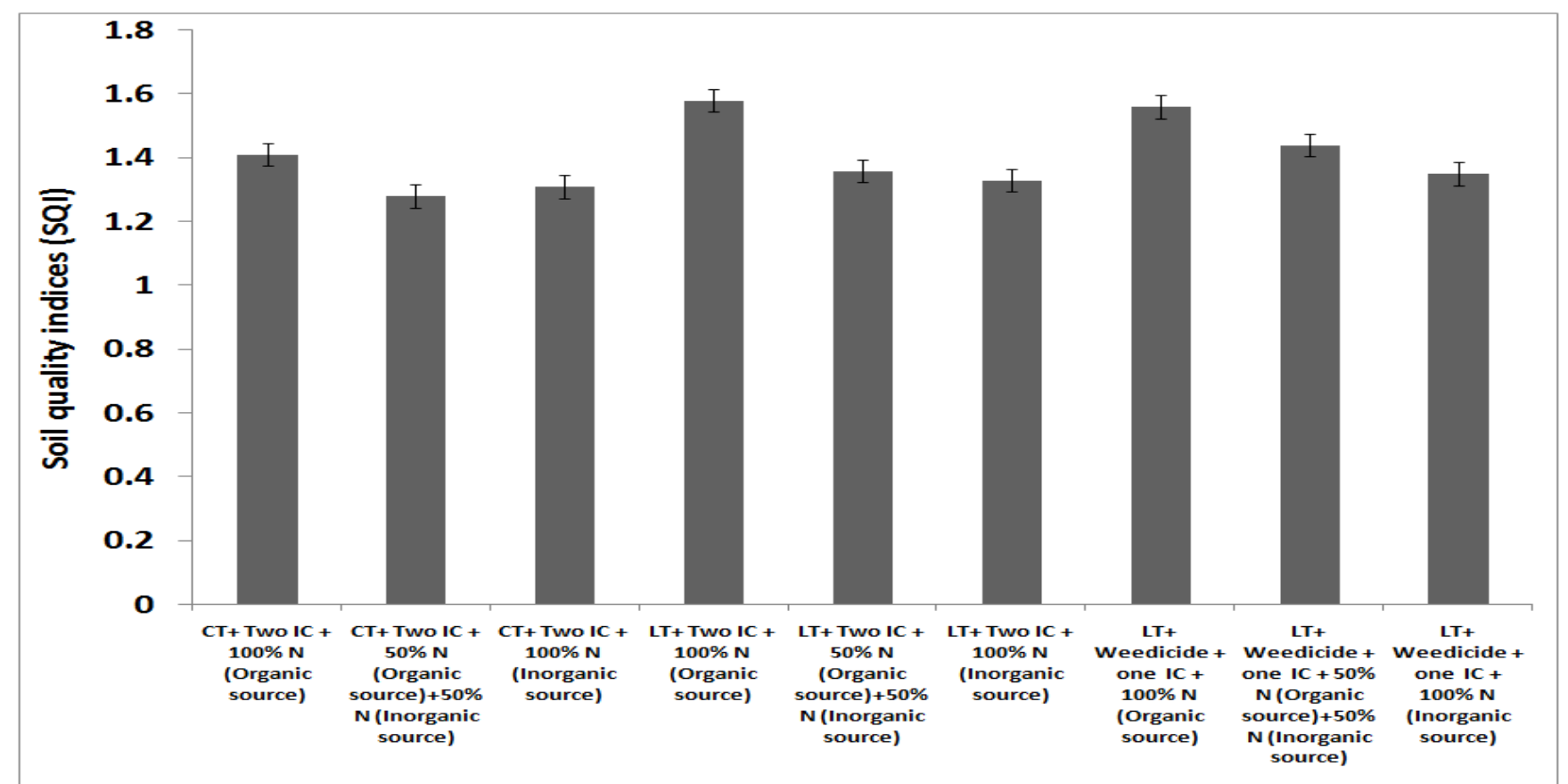

Fig 6: Soil quality indices (SQI) as influenced by different tillage and nutrient management treatments under maize based cropping system

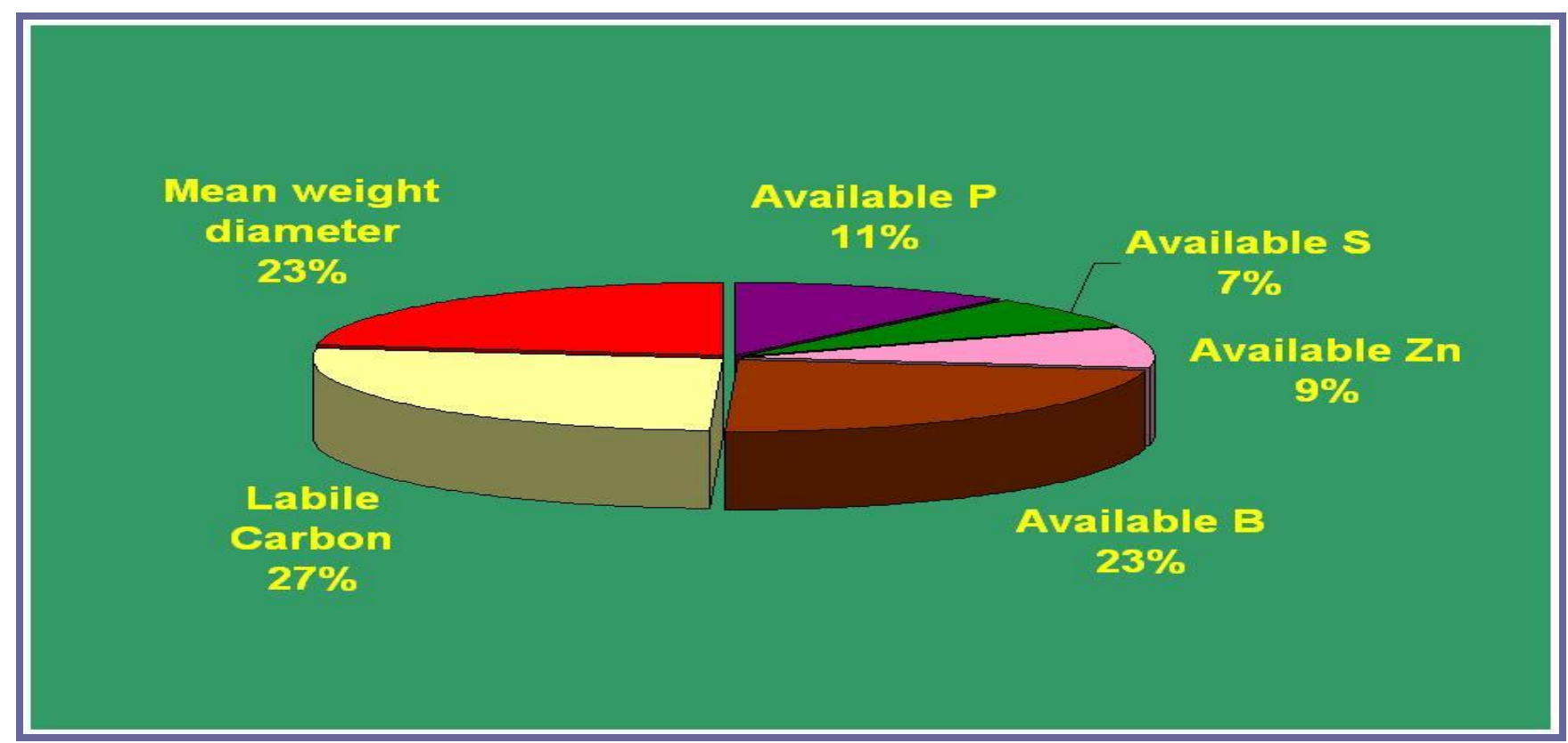

Fig 7: Percent contribution of key soil quality indicators towards soil quality indices asinfluenced by tillage and nutrient management treatments under maize based cropping system

To conclude, it can be stated that that after four years of experimentation, the increase in the organic carbon was highest when the application of nutrients was made through 100\% organic sources. Application of nutrients through inorganic sources recorded significantly highest influence on the available $\mathrm{N}$ and $\mathrm{P}$. Among the secondary nutrients, available $S$ was significantly influenced by both the tillage and nutrient management treatments. Application of $100 \%$ organic sources recorded the highest available B content. Significant influence of tillage was observed on microbial biomass carbon, dehydrogenase activity and labile carbon. On an average basis, the practice of $L T+$ weedicide + one interculture and LT + Two IC maintained significantly highest mean weight diameter and were at par with each other. Application of 
nutrients through $100 \%$ organic sources recorded significantly highest mean weight diameter. Finally, when soil quality indices were compared, the application of $100 \% \mathrm{~N}$ through organic sources maintained significantly highest soil quality index (SQI) followed by application of $50 \% \mathrm{~N}$ through organic sources + $50 \% \mathrm{~N}$ through inorganic sources which were at par with the application of $100 \% \mathrm{~N}$ through inorganic sources. The important soil parameters viz., OC, N, P, S, Zn, Cu, B, DHA, MBC, LC, BD

\section{REFERENCES}

AICRPDA (2003) Research publications and recommendations in dryland agriculture: An annotated bibliography of 1972-2002, ed. K. P. R. Vittal, H. P. Singh, G. R. Maruthi Sankar, G. RavindraChary, T. Sri Jaya, and Vibha Srivastava. Hyderabad, India: All-India Coordinated ResearchProject, Central Research Institute for Dryland Agriculture.

Andrews, S.S., Mitchell, J.P., Mancinelli, R., Karlen, D.L., Hartz, T.K., Horwarth, W.R., Pettygrove, G.S., Scow, K.M., and Munk, D.S. (2002a) On farm assessment of soil quality in California's Central Valley. Agronomy Journal 94: 12-23

Brejda, J.J., Karlen, D.L., Smith, J.L., and Allan, D.L. (2000b) Identification of regional soil quality factors and indicators: II. Northern Mississippi loess hills and Palouse prairie.Soil Science Society of America Journal 64: 2125-2135.

Brejda, J.J., Moorman, T.B., Karlen, D.L., and Dao, T.H. (2000a) Identification of regional soil quality factors and indicators: I. Central and southern high plains. Soil Science Society of America Journal 64:2115-2124.

Dalal, R.C., and D. Moloney.(2000) Sustainability indicators of soil health and biodiversity. In Management for Sustainable Ecosystems, ed. P. Hale, A. Petrie, D. Moloney, and P. Sattler,101108. Brisbane: Centre for Conservation Biology.

Doran, J.W., and T.B. Parkin.(1994) Defining and assessing soil quality. In Defining soil quality fora sustainable environment, ed. J. W. Doran, D. C. Coleman, D. F. Bezdicek, and B.A. Stewart,321. and MWD were identified as the key indicators for maize cropping system in Inceptisols of the study region viz Rakhdhiansar. The findings of this study clearly indicate that the appropriate combination of tillage and nutrient managementcomponents can effectively help in maintaining higher soil quality indices in these soils. The result and methodology of the present study will be highly useful to different stake holders such as land managers, researchers, students, farmers and policy planners.

Madison, Wisc: Soil Science Society of America.

Doran, J. W., Sarrantonio, M.and M. Liebig. (1996) Soil health and sustainability. In ed. D. L. Sparks, Advances in Agronomy vol. 56, 1-54. San Diego, Calif.: Academic Press.

Eck, H. V., and B. A. Stewart.(1998) Effects of long-term cropping on chemical aspects of soil quality. Journal of Sustainable Agriculture 12:5-20.

FAI. (2011) Fertiliser statistics. New Delhi, India: Fertilizer Association of India.

Jenkinson, D.S., and Powlson, D.S. (1976) The effects of biocidal treatments on metabolism in soil V.A. method for measuring soil biomass. Soil Biology and Biochemistry 8: 209-213.

Lenhard, G. (1956) Die dehydrogenase-activitat des Bodens also Mass fur die mikroorganis- mentatigkeit im Boden. Zeitschrift fur Pflanzenernaehr. Dueng und Bodenkd 73:1-11.

Lindsay, W.L., and Norvell, W.A. (1978) Development of a DTPA soil test for zinc, iron, manganese and copper. Soil Science Society of America Journal 42: 421-428.

Malhi, S.S., J.T. Harapiak, M. Nyborg, and K.S. Gill. (2000) Effects of long-term applications of various nitrogen sources on chemical soil properties and composition of bromegrass hay. Journal of Plant Nutrition 23:903-912.

Miller, R.O., Vaughan, B. and Kutoby-Amacher, J. (2001) Extraction of soil boron with DTPA-sorbitol.Soil and Plant Analysis Spring 4:5-10. 
Mohammad, S. K., and S. Mohammad.(1999) Long-term effects of fertilizers and integrated nutrient supply systems in intensive cropping on soil fertility, nutrient uptake, and yield of rice.Journal of Agricultural Science 133: 365-370.

Noble, A. D., and A. P. Hurney (2000) Long-term effects of lime additions on sugarcane yield and soil chemical properties in north Queensland.Experimental Agriculture 36: 397-413.

Sharma J.C. and S.K. Chaudhary (2007) Vertical distribution of micronutrient cations in relationto soil characteristics in lower Shiwaliks of Solan district of northwest Himalayas. Journal of Indian Society of Soil Science 55:40-44.

Sharma, R.K., K.S. Babu, P. S. Chhokar, and A. K. Sharma (2004) Effect of tillage on termites, weed incidence, and productivity of spring wheat in rice-wheat system of north western Indian plains. Crop Protection 23:1049-1054.

Sharma, K.L.Ravindra Chary, G., Sammi Reddy, K., Singh, A.P., Vikas Abrol, Sharma, Anil, Hemant Dadhich, Munna Lal, Gopinath, K.A., Narsimlu, B., Osman, M., Srinivas, K., Indoria, A.K., Suma Chandrika, D., Vasavi, M., Haindavi P. and Lakshmi Aruna Gayatri, D. (2019) Effect of integrated nutrient management on soil quality indicators and soil quality indices in hill and mountainous inceptisol soils in northern india under maize (zea mays) - black gram (vigna mungo) system. India Indian Journal Dryland Agriculture Research\& Development 34(1): 01-08

Sharma, K.L.Ravindra Chary, G., Sammi Reddy, K., Munna Lal, Indoria, A.K., Srinivas, K., Prabhakar, M., Baskar, K., Elamathi, S., Sanjiv Kumar, V., Ananda Raj, N., Suma Chandrika, D., Lakshmi Aruna Gayatri, D., Gopinath, K.A., Osman, M., Narsimlu, B. and Chandra Sekhar, Ch. (2019) Effect of conjunctive use of inorganic and organic sources of nutrients on soil quality parameters, key indicators and soil quality indices (sqis) under sorghum + cowpea intercropping system in rainfed vertisol soils of southern. India Indian Journal Dryland Agriculture Research\& Development 34(2) : 38-50

Snedecor, G., Cochran, W., and Cox, D. (1989) Statistical Methods. (The lowa State University Press: Ames).

Subbarao, G.V., C. Renard, W. A. Payne, and A. Bationo (2000) Long-term effect of tillage, phosphorus fertilization, and crop rotation on pearl millet-cowpea productivity in the West African. Experimental Agriculture 36: 243-264.

Suri, V.K. (2007) Perspectives in soil health management: A looking glass. Journal of Indian Society of Soil Science 55 (4): 436-443.

Unger, P.W., N.S. Andrew, J. L. Steiner, R. I. Papendick, and W. M. Edwards.(1998) Soil management research for water conservation and quality.In Advances in soil and water conservation, ed. F. J. Pierce and W. W. Frye. Chelsea, Mich.: Ann Arbor Press.

Van Bevel, C.H.M. (1949) Mean weight diameter of soil aggregates as a statistical index of aggregation. Soil Science Society of America Proceedings 14: 20-23.

Wander, M.M., and Bollero, G.A. (1999) Soil quality assessment of tillage impacts in Illinois. Soil Science Society of America Journal 63: 961-971.

Weil, R.R., Islam, K.R., Stine, M.A., Gruver, J.B., Sampson-Liebeg, S.E. (2003) Estimating active carbon for soil quality assessment: A simplified method for laboratory and field use. American Journal of Alternative Agriculture 18 (1): 3-17

Yoder, R.E. (1936) A direct method of aggregate analysis of soils and a study of the physical nature of erosion losses. Journal of American Society of Agronomy 28:337-351. 